\title{
The Effect of Feed and Temperature Regimen on Lipid Oxidation in Muscles of Broiler Chickens
}

\author{
A. HALAMÍČKOVÁ, L. VORLOVÁ, M. SMUTNÁ, E. STRAKOVÁ, P. SUCHÝ, V. VEČEREK
}

University of Veterinary and Pharmaceutical Sciences Brno, Faculty of Veterinary Hygiene and Ecology, Brno, Czech Republic

Received April 11, 2005

Accepted November 10, 2005

\begin{abstract}
Halamíčková A., L. Vorlová, M. Smutná, E. Straková, P. Suchý, V. Večerek: The Effect of Feed and Temperature Regimen on Lipid Oxidation in Muscles of Broiler Chickens. Acta Vet. Brno 2006, 75: 39-48.

The paper presents the effects of temperature and feed composition on the stability of lipids in breast and thigh muscles of COBB 500 meat hybrids. The chickens were reared in accordance with the technological procedure. The diet of experimental groups contained Proenergol in combination with Energol; the diet of control group chickens contained Proenergol and soybean oil. In the control groups and in half of the experimental groups, the temperature was reduced in agreement with the technological procedure, while it was kept at the constant level of $31^{\circ} \mathrm{C}$ in other groups. The feeding continued up to the age of 42 days. The level of lipid oxidation was determined using malondialdehyde assays. No differences between individual groups of chickens were found in the breast muscle. In the thigh muscle, the introduction of Energol resulted in non-significant differences between the control and chickens kept in heat stress conditions. Negative correlation between lipid oxidation and live weight was established in control chickens fed soybean oil $(p<0.05)$. This correlation was positive $(p<0.05)$ in young male chicks fed Energol and kept at constantly increased temperature.
\end{abstract}

Malondialdehyde, feed supplement, temperature regimen, broiler chickens, breast and thigh muscles

Poultry production appears as very advantageous from the environmental point of view as well as regarding the production of safe foodstuffs. Broiler feeding is one of its most important and fastest developing branches. However, broiler require relatively high doses of proteins. The supply of these components in the form of animal meal is becoming increasingly controversial on the grounds of possible prion transfer. This situation results in search for new diets that would neither harm the chickens' state of health nor negatively affect the production and quality of end products.

The recently developed food supplement Proenergol ranks among the wide-spectrum protein-mineral-energy products. It is made from rapeseed press cake containing $15 \%$ of oil, or from seeds containing $40 \%$ of oil. In addition to containing current sources of energy, calcium and magnesium salts of fatty acids and glycerol contribute to the energy value of this feed. The product is distinguished by its high content of saturated fatty acids and a low content of polyene fatty acids. Polyene acids are important components of structural lipids of cell membranes. Nutritional requirement for arachidonic acid and acids derived from it can be decreased if the diet contains linoleic and n-linolenic acids in a sufficient quantity: from these, the organism can synthesise other members of polyene acids series n- 6 and n-3 (Murray et al. 2002). Manifestations of the deficit in essential fatty acid have been known for a long time: they include slow growth, fertility disorders, disorders of the urinary tract and skin. Essential fatty acids are also precursors of eicosanoids - substances with pronounced physiological and pharmacological effects. They are known as prostacyclins,

Address for correspondence:

RNDr. Alena Halamíčková

Department of Biochemistry, Chemistry and Biophysics

Faculty of Veterinary Hygiene and Ecology

University of Veterinary and Pharmaceutical Sciences Brno

Palackého 1-3, 61242 Brno, Czech Republic

Phone: +420541562602

E-mail: halamickovaa@vfu.cz

http://www.vfu.cz/acta-vet/actavet.htm 
thromboxanes and leukotrienes, and they affect the functioning of many organ systems, among others also the inflammatory processes (Murray et al. 2002; Parmentier et al. 1997).

The spectrum of fatty acids received through the diet affects the metabolism and subsequently the lipid composition of meat and other edible parts of broiler carcasses (Du et al. 2000; Lauridsen et al. 1997). Synthesised unsaturated lipids alter the sensory properties of meat. First and foremost, the liquid consistence of poultry fat makes the product unacceptable. Lipid oxidation products are considered the most serious cause of this phenomenon. Polyene fatty acids are easily subject to oxidation caused by triplet oxygen, transition metals, photosensitisers and lipoxygenases (Guillén-Sans and GuzmánChozas 1998; Velíšek 1999). The resulting secondary products of lipoperoxidation adversely affect the taste, aroma and shelf life of the meat and meat products (Schneiderová 2002). The effects of some of these products on the human organism cannot be neglected (Basu and Marnett 1983). Saturated and monoene acids are more stable to oxidation than polyene acids (Sugihara et al. 1994; Velíšek 1999). Sanz et al. (1999) have demonstrated the higher stability of saturated fatty acids when comparing various fat sources in the broilers' diet.

Energol is a feed supplement intended to mitigate heat stress. After hatching, the thermoregulation system of the chicks is insufficiently developed. For one-day chickens, the temperature optimum ranges from $32{ }^{\circ} \mathrm{C}$ to $33{ }^{\circ} \mathrm{C}$, decreasing to $20-23{ }^{\circ} \mathrm{C}$ within about 28 days. At these temperatures, the chickens are not markedly stressed by thermoregulatory mechanisms. Increased demands on the microclimate, first and foremost on the temperature, become manifest even in the later period as a consequence of the chickens' size, absence of sweat glands, the presence of plumage, and fat accumulation in the abdominal cavity. High environmental temperatures are connected with lower feed consumption and subsequent restricted motor activity (Donkoh 1989), and also with a reduction in live weight and growth rate. Hunton (1995) draws attention to the vasodilatation of small vessels and to the acceleration of heart and respiratory rate. The chicks cool down by means of water evaporation from the respiratory tract mucous membranes or by lifting their wings and so increasing their body surface. Increased water consumption has been often recorded, and even dehydration cannot be excluded. From the point of view of physiology, increased carbon dioxide production can result in subsequent changes in the acid-base balance. As regards biochemical indices, a reduction in plasmatic proteins is important (D onk oh 1989) as well as a decrease in plasma and tissue concentration of mineral components such as iron, zinc and copper, which are connected with the lipid oxidation (Velíšek 1999). Heat stress affects the organism's antioxidant capacity by interfering with A, E and C vitamin absorption and by increasing their consumption (Naziroglu et al. 2000; S a h in et al. 2001). Heavy individuals are most often affected by heat stress; sudden death can ensue if the heat stress is severe. Diet supplementation with antioxidant vitamins as a means of alleviating the effects of heat stress is currently under consideration (S a hin et al. 2001).

The objective of the present paper was the investigation of oxidative changes to intramuscular lipids of breast and thigh muscles of broiler chickens COBB 500 after feeding the recently developed protein-mineral-energy supplementary feed Proenergol and the feed supplement Energol in connection with the antioxidative and prooxidative effects of feed mixtures and the temperature regimen.

\section{Materials and Methods}

Biological material

The feeding experiment was carried out in the barns of the Institute of Nutrition, Dietetics and Vegetabilia Hygiene of the University of Veterinary and Pharmaceutical Sciences Brno. Six hundred unsexed one-day broiler chicks of the meat hybrid COBB 500 were selected for the experiment. The chicks were divided into six groups, 
each containing 100 individuals. The groups differed with respect to sex, feed composition and temperature regimen.Odd-numbered groups consisted of females, even-numbered ones of males.

All groups were housed on deep bedding in agreement with the technological instruction for COBB 500 chicks, with controlled light, temperature, animal hygiene and feeding regimen. For the whole feeding period, the broiler chickens were fed ad libitum feed mixtures prepared for this experiment by AgroKonzulta s.r.o., Žamberk. Feed mixture BR 1 was fed to chickens aged 1 to 13 days, feed mixture BR 2 was fed from day 14 to day 30 , and feed mixture BR 3 from the 31 st to the $42^{\text {nd }}$ day. Groups one, two, five and six (SEn) had Proenergol V 80, Energol R and Energol S included in their diet. In groups three and four (SSo), serving as controls, Energol was replaced with soybean oil. Formulas for feed mixtures for experimental and control groups are given in Table 1.

Table 1. Formulas for feed mixtures for experimental and control groups of broiler chickens

\begin{tabular}{|l|c|c|c|c|c|c|}
\hline & \multicolumn{3}{|c|}{ Experimental groups } & \multicolumn{3}{c|}{ Control groups } \\
\hline Component [\%] & BR 1 & BR 2 & BR 3 & BR 1 & BR 2 & BR 3 \\
\hline Wheat + ZY 68 & 51.80 & 59.50 & 66.90 & 52.30 & 60.10 & 67.70 \\
\hline $\begin{array}{l}\text { Extracted soybean grouts } \\
\text { 46\% H }\end{array}$ & & & & & & \\
\hline Microelements & 24.00 & 20.00 & 17.00 & 24.00 & 20.00 & 17.00 \\
\hline Lys - HCl 100\% & 0.50 & 0.45 & 0.50 & 0.50 & 0.50 & 0.50 \\
\hline D, L-Met 100\% & 0.24 & 0.47 & 0.60 & 0.47 & 0.47 & 0.60 \\
\hline L-Thr 100\% & 0.10 & 0.25 & 0.22 & 0.24 & 0.25 & 0.22 \\
\hline Monokal MCP- F & 0.75 & 0.60 & 0.11 & 0.10 & 0.11 & 0.13 \\
\hline Mononatriumphosphate & 0.48 & 0.44 & 0.50 & 0.75 & 0.60 & 0.50 \\
\hline Feed salt & 0.16 & 0.18 & 0.15 & 0.16 & 0.44 & 0.50 \\
\hline Vitex Q & 2.50 & 2.50 & 2.50 & 2.50 & 2.50 & 0.15 \\
\hline Ground limestone & - & - & - & 0.80 & 1.15 & 1.20 \\
\hline Proenergol V 80 & 5.00 & 5.00 & 5.00 & 5.00 & 5.00 & 5.00 \\
\hline Proenergol V 100 & 10.00 & 5.00 & - & 10.00 & 5.00 & - \\
\hline Energol R & 3.00 & 3.50 & 4.00 & - & - & - \\
\hline Energol S & 1.00 & 2.00 & 2.00 & - & - & - \\
\hline Soybean oil & - & - & - & 2.70 & 3.75 & 4.00 \\
\hline
\end{tabular}

The feeding was provided in plastic tube feeders and water supply from suspended poultry drinkers (type PLASSON MK II). In experimental groups one, two (SEn) and in control groups (SSo), the temperature was gradually reduced in accordance with the technological instruction for COBB 500 from $31{ }^{\circ} \mathrm{C}$ to $21{ }^{\circ} \mathrm{C}$. In experimental groups five and six (SEn), the temperature was maintained at the level of $31{ }^{\circ} \mathrm{C}$ for the whole period of feeding. The feeding continued until the age of 42 days. At this age, the chickens were slaughtered and the experiment was evaluated. For the malondialdehyde determination, ten animals were randomly selected from each group. Deplumed, eviscerated and cleansed chickens were individually packed into closely adhering polyethylene bags and stored separately in a freezer box at the temperature of $-18{ }^{\circ} \mathrm{C}$.

Malondialdehyde determination

Malondialdehyde was determined within two months of slaughter. On the day of analysis, the chickens were removed from the freezer. After two-hour defreezing at room temperature, breast and thigh muscles were separated and samples homogenised by double grinding in a meat mincer, always for one minute.

Fluorometric method according to Tanizawa et al. (1981) was used for the analysis. Each sample was processed in duplicate. The samples were analysed by series. Each series consisted of 10 measurements, 4 samples prepared in duplicate and 2 blind samples. The content of the MDA - TBA complex in butanol phase $\left(\mathrm{x}_{\mathrm{MDA}}\right)$ was read from the calibration curve. The results were expressed as $\mu \mathrm{mol}$ of MDA per $1 \mathrm{~kg}$ of wet tissue $(\mathrm{w} / \mathrm{w})$ as follows:

$\mathrm{m}_{\mathrm{MDA}}=\mathrm{x}_{\mathrm{MDA}}$. conversion factor

The values measured were processed using the statistical program SigmaStat $₫$, version 2.0. In addition to the calculation of basic statistical indices, the correlation between the malondialdehyde values and live weight was also calculated.

\section{Feed analysis}

\section{Results}

The relative abundance of lipids and their important saccharide precursors in the feed rations is shown in Table 2 . The fat content is not specified by a standard. Fatty acids were 
supplied into the feed mixtures in the form of Proenergol plus soybean oil, or Proenergol plus Energol. The feed supplements were the source of saturated fatty acids, among which palmitic, stearic and myristic acids were prevalent. The butyric, lauric, caprinic, capronic and caprylic acid content did not exceed 6\%. Oleic acid was dominant among monoene acids. Polyene acid content did not exceed $6 \%$, most of it being the linoleic acid.

Table 2. Lipid and saccharide feed components

\begin{tabular}{|c|c|c|c|c|c|}
\hline & & Lipids & $\begin{array}{c}\text { Linoleic } \\
\text { Acid }\end{array}$ & Starch & $\begin{array}{c}\text { Other } \\
\text { saccharides }\end{array}$ \\
\hline \multirow[t]{4}{*}{$\begin{array}{l}\text { BR } 1 \\
\end{array}$} & Standard $[\mathrm{g}]$ & - & $\min .12 .500$ & - & - \\
\hline & SSo $[\mathrm{g}]$ & 66.203 & 24.329 & 330.425 & 32.479 \\
\hline & SEn $[\mathrm{g}]$ & 68.334 & 16.671 & 327.475 & 32.364 \\
\hline & $\mathrm{SEn}-\mathrm{SSo} / \mathrm{SSo}[\%]$ & +3.22 & -31.48 & -0.89 & -0.35 \\
\hline \multirow{2}{*}{$\begin{array}{l}\text { Meeting of } \\
\text { standard [\%] }\end{array}$} & SSo & - & 194.6 & - & - \\
\hline & SEn & - & 133.4 & - & - \\
\hline \multirow[t]{4}{*}{ BR 2} & Standard $[\mathrm{g}]$ & - & $\min .12 .000$ & - & - \\
\hline & SSo $[\mathrm{g}]$ & 70.376 & 28.998 & 372.560 & 30.873 \\
\hline & SEn $[\mathrm{g}]$ & 72.676 & 19.323 & 369.020 & 30.735 \\
\hline & SEn-SSo/SSo [\%] & +3.27 & -33.36 & -0.95 & -0.45 \\
\hline \multirow{2}{*}{$\begin{array}{l}\text { Meeting of } \\
\text { standard [\%] }\end{array}$} & SSo & - & 241.7 & - & - \\
\hline & SEn & - & 161.0 & - & - \\
\hline \multirow[t]{4}{*}{ BR 3} & Standard [g] & - & $\min .10 .000$ & - & - \\
\hline & SSo $[\mathrm{g}]$ & 66.699 & 29.667 & 414.065 & 30.071 \\
\hline & SEn $[\mathrm{g}]$ & 70.173 & 19.260 & 409.345 & 29.887 \\
\hline & SEn-SSo/SSo [\%] & +5.21 & -35.08 & -1.14 & -0.61 \\
\hline \multirow{2}{*}{$\begin{array}{l}\text { Meeting of } \\
\text { standard [\%] }\end{array}$} & SSo & - & 296.7 & - & - \\
\hline & SEn & - & 192.6 & - & - \\
\hline
\end{tabular}

In comparison with the controls, the diet of experimental groups had a higher fat content and lower linoleic acid content in all stages of feeding. No differences in the quantity and composition of substances important for the biosynthesis of endogenous lipids (starch and other saccharides) were present in the formulas for control and experimental groups.

The content of the most important antioxidants is shown in Table 3. It shows a tendency towards increased antioxidant capacity due to endogenous supply of antioxidants, first of all vitamin $\mathrm{E}$, vitamin $\mathrm{A}$ and carotenes in the feed mixtures BR1 to BR3. Vitamin $\mathrm{C}$ is not standardised and was not present in the feed; the same holds good for xanthophylls. As regards the antioxidant precursors, choline and selenium are present or quantified; as for the metals involved in lipid oxidation processes, iron, copper, manganese, cobalt, nickel and chromium are present. The contents of the last three metals are not standardized. There are no significant differences between the tested groups in the content of amino acids that can react with secondary lipid oxidation products.

The results of malondialdehyde assays in the breast and thigh muscle

In the breast muscle of the tested groups, malondialdehyde values in the range of 1.07 $9.82 \mu \mathrm{mol} \cdot \mathrm{kg}^{-1}$ wet tissue were recorded. The statistical evaluation of the results of malondialdehyde assays in the breast muscle of females and males is shown in Table 4. No significant differences between the groups and between males and females of the same group could be found. In the groups fed soybean oil, the mean value amounted to $3.65 \mu \mathrm{mol} \cdot \mathrm{kg}^{-1}$ wet tissue, in groups with Energol, kept in the same temperature conditions as the control groups, it amounted to $3.51 \mu \mathrm{mol} \cdot \mathrm{kg}^{-1}$ and to $3.48 \mu \mathrm{mol} \cdot \mathrm{kg}^{-1}$ wet tissue in groups kept at constantly increased temperature. 
Table 3. Feed components with antioxidative and prooxidative effects

\begin{tabular}{|c|c|c|c|c|c|c|c|c|c|c|}
\hline \multicolumn{2}{|l|}{ Indices } & \multirow{2}{*}{$\frac{\text { Vit.E }}{}$} & \multirow{2}{*}{$\begin{array}{l}\text { Vit.A } \\
{[\mathrm{m} . \mathrm{j} .]}\end{array}$} & \multirow{2}{*}{$\begin{array}{c}\text { Caroten } \\
-\end{array}$} & \multirow{2}{*}{$\begin{array}{l}\text { Cholin } \\
1800.00\end{array}$} & \multirow{2}{*}{$\begin{array}{l}\mathrm{Se} \\
0.15\end{array}$} & \multirow{2}{*}{$\begin{array}{l}\mathrm{Fe} \\
80.00\end{array}$} & \multirow{2}{*}{$\begin{array}{l}\mathrm{Cu} \\
8.00\end{array}$} & \multirow{2}{*}{$\begin{array}{c}\mathrm{Mn} \\
100.00\end{array}$} & \multirow{2}{*}{$\begin{array}{l}\text { Co } \\
-\end{array}$} \\
\hline BR 1 & $\begin{array}{l}\text { Standard } \\
\min .[\mathrm{mg}]\end{array}$ & & & & & & & & & \\
\hline & SSo [mg] & $57 ., 8$ & 15000 & 0.350 & 1620.64 & 0.23 & 137.20 & 14.02 & 126.36 & 0.44 \\
\hline & $\operatorname{SEn}[\mathrm{mg}]$ & 57.7 & 15000 & 0.320 & 1616.64 & 0.23 & 134.10 & 14.00 & 125.19 & 0.44 \\
\hline & $\begin{array}{l}\text { SEn-SSo/Sso } \\
{[\%]}\end{array}$ & -0.17 & 0 & -8.57 & -0.25 & 0 & -2.26 & -0.14 & -0.93 & 0 \\
\hline \multirow{2}{*}{$\begin{array}{l}\text { Meeting of } \\
\text { standard [\%] }\end{array}$} & SSo & 115.6 & 100.0 & - & 90.04 & 153.3 & 171.5 & 175.3 & 126.4 & - \\
\hline & SEn & 115.4 & 100.0 & - & 89.81 & 153.3 & 167.6 & 175.0 & 125.2 & - \\
\hline \multirow[t]{4}{*}{ BR 2} & $\begin{array}{l}\text { Standard } \\
\text { min. [mg] }\end{array}$ & 50.0 & 12000 & - & 1600.00 & 0.15 & 80.00 & 8.00 & 100.00 & - \\
\hline & SSo [mg] & 53.8 & 13500 & 0.400 & 1527.60 & 0.22 & 129.12 & 12.94 & 117.83 & 0.39 \\
\hline & SEn [mg] & 53.7 & 13500 & 0.370 & 1522.80 & 0.21 & 124.72 & 12.91 & 116.19 & 0.39 \\
\hline & $\begin{array}{l}\text { SEn-SSo/SSo } \\
{[\%]}\end{array}$ & -0.19 & 0 & -7.5 & -0.31 & -4.55 & -3.41 & -0.23 & -1.39 & 0 \\
\hline \multirow{2}{*}{$\begin{array}{l}\text { Meeting of } \\
\text { standard [\%] }\end{array}$} & SSo & 107.6 & 112.5 & - & 95.5 & 146.7 & 161.4 & 161.8 & 117.8 & - \\
\hline & SEn & 107.4 & 112.5 & - & 95.2 & 140.0 & 155.9 & 161.4 & 116.2 & - \\
\hline \multirow[t]{4}{*}{ BR 3} & $\begin{array}{l}\text { Standard min. } \\
{[\mathrm{mg}]}\end{array}$ & 50.0 & 12000 & - & 1400.00 & 0.10 & 80.00 & 8.00 & 100.00 & - \\
\hline & SSo [mg] & 59.8 & 15000 & 0.45 & 1559.32 & 0.23 & 137.09 & 13.60 & 129.18 & 0.42 \\
\hline & SEn [mg] & 59.7 & 15000 & 0.41 & 1552.92 & 0.22 & 132.43 & 13.57 & 127.42 & 0.42 \\
\hline & $\begin{array}{l}\text { SEn-SSo/SSo } \\
{[\%]}\end{array}$ & -0.17 & 0 & -8.89 & -0.41 & -4.35 & -3.40 & -0.22 & -1.36 & 0 \\
\hline \multirow{2}{*}{$\begin{array}{l}\text { Meeting of } \\
\text { standard [\%] }\end{array}$} & SSo & 119.6 & 125.0 & - & 111.4 & 230.0 & 171.4 & 170.0 & 129.2 & - \\
\hline & SEn & 119.4 & 125.0 & - & 110.9 & 220.0 & 165.5 & 169.6 & 127.4 & - \\
\hline
\end{tabular}

Table 4. Evaluation of the malondialdehyde content in breast muscles of male and female broiler chickens

\begin{tabular}{|c|c|c|c|c|c|c|c|c|c|}
\hline $\begin{array}{l}\text { Statistical } \\
\text { Parameters }\end{array}$ & \multicolumn{9}{|c|}{ MDA $\left[\mu \mathrm{mol}^{\prime} \cdot \mathrm{kg}^{-1}\right]$ Wet tissue } \\
\hline Group & $1($ P) & $2(0)$ & $1+2$ & $3($ ( $)$ & $4\left(0^{\pi}\right)$ & $3+4$ & $5($ 우 $)$ & $6\left(0^{n}\right)$ & $5+6$ \\
\hline Mean & 4.13 & 3.32 & 3.51 & 3.65 & 3.70 & 3.66 & 3.57 & 3.36 & 3.48 \\
\hline SD & 2.34 & 1.04 & 1.20 & 1.30 & 1.37 & 1.37 & 1.11 & 1.10 & 1.14 \\
\hline
\end{tabular}

$\mathrm{SD}=$ standard deviation

Fig 1. Distribution of breast muscle samples of broiler chickens with respect to malondialdehyde content

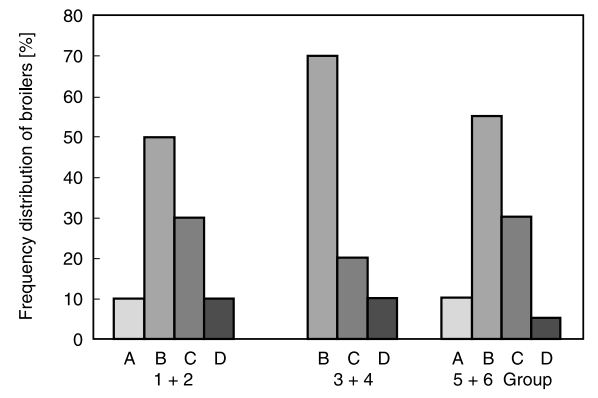

Malondialdehyde content in series:

$\mathrm{A}=$ to $2.00 \mu \mathrm{mol} / \mathrm{kg} \quad \mathrm{B}=2.01-4.00 \mu \mathrm{mol} / \mathrm{kg} \quad \mathrm{C}=4.01-5.00 \mu \mathrm{mol} / \mathrm{kg} \quad \mathrm{D}=$ over $5.01 \mu \mathrm{mol} / \mathrm{kg}$ 
Table 5. Evaluation of the malondialdehyde content in thigh muscles of male and female broiler chickens

\begin{tabular}{|c|c|c|c|c|c|c|c|c|c|}
\hline Statistical & \multicolumn{9}{|c|}{ MDA $\left[\mu \mathrm{mol}^{\prime} \mathrm{kg}^{-1}\right]$ Wet tissue } \\
\hline Group & $1($ ㅇ) & $2\left(0^{1}\right)$ & $1+2$ & $3(9)$ & $4\left(0^{1}\right)$ & $3+4$ & $5($ ㅇ) & $6\left(0^{1}\right)$ & $5+6$ \\
\hline Mean & 9.85 & 6.11 & 7.99 & 6.40 & 4.83 & 5.61 & 7.60 & 7.21 & 7.38 \\
\hline SD & 2.95 & 3.22 & 3.56 & 3.59 & 1.22 & 2.73 & 3.69 & 3.63 & 3.32 \\
\hline
\end{tabular}

$\mathrm{SD}=$ standard deviation

Statistically significant difference between group: $3+4$ and $1+2(p<0.05) 1-2(p<0.05)$

The distribution of broiler chicks into classes according to the values measured is shown in Fig. 1. In all groups, the category with values between 2.01 and $4.00 \mu \mathrm{mol} \cdot \mathrm{kg}^{-1}$ wet tissue was most frequent. In the experimental groups, the replacement of the soybean oil with Energol was manifested as occurrence of individuals in the class $\leq 2 \mu \mathrm{mol} \cdot \mathrm{kg}^{-1}$ wet tissue in both temperature regimens.

The results of malondialdehyde assays obtained in the thigh muscle are shown in Table 5. Values in the range of $2.33-14.39 \mu \mathrm{mol} \cdot \mathrm{kg}^{-1}$ wet tissue were measured in the tested chickens. In the groups fed soybean oil, the mean value amounted to $5.61 \mu \mathrm{mol} \cdot \mathrm{kg}^{-1}$ wet tissue, in groups with Energol kept at the same temperature as the control groups, it amounted to $7.99 \mu \mathrm{mol} \cdot \mathrm{kg}^{-1}$ wet tissue, and in groups kept at constantly elevated temperature, this value was $7.38 \mu \mathrm{mol} \cdot \mathrm{kg}^{-1}$ wet tissue. The difference between control and experimental chickens kept at the same temperature was significant. The effect of Energol was manifest in the females in the first instance; the formation of malondialdehyde was reduced in chickens kept at the temperature of $31{ }^{\circ} \mathrm{C}$.

Fig. 2. Distribution of thigh muscle samples of broiler chickens with respect to malondialdehyde content

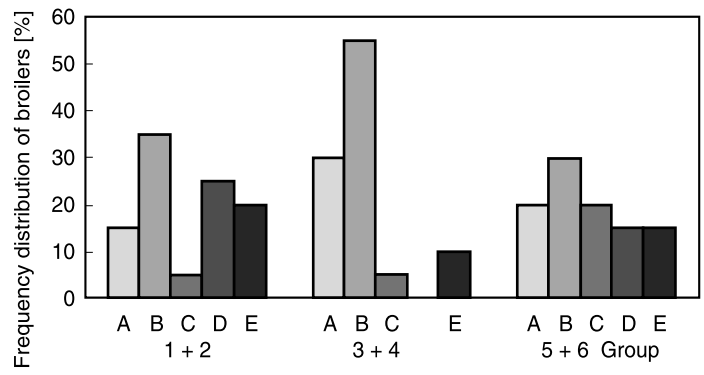

Malondialdehyde content in series:

$\mathrm{A}=2.00-4.00 \mu \mathrm{mol} / \mathrm{kg}$

$\mathrm{D}=9.01-11.00 \mu \mathrm{mol} / \mathrm{kg}$

$\mathrm{B}=4.01-7.00 \mu \mathrm{mol} / \mathrm{kg}$

$\mathrm{E}=$ over $11.01 \mu \mathrm{mol} / \mathrm{kg}$

$\mathrm{C}=7.01-9.00 \mu \mathrm{mol} / \mathrm{kg}$

The distribution of broiler chickens into classes according to the malondialdehyde values is shown in Fig. 2. In the control group, the class with $4.01-7.00 \mu \mathrm{mol} \cdot \mathrm{kg}^{-1}$ wet tissue was most abundant. The substitution of soybean oil with Energol resulted in a more uniform distribution of chickens into individual classes in comparison with the controls. The class containing 7.01 $-9.00 \mu \mathrm{mol} \cdot \mathrm{kg}^{-1}$ wet tissue was markedly reduced in the group kept at control temperature.

A significant difference in malondialdehyde values between the breast and thigh muscles was demonstrated; in males and females of the control group, the level of significance was slightly lower $(p<0.002)$ than in the experimental groups $(p<0.001)$.

In the breast muscle, we failed to corroborate the correlation between live weight and malondialdehyde values. The relations between the variables monitored in the thigh muscles 
are shown in Table 6. In the control groups, negative correlations were demonstrated for both sexes, with higher statistical significance in the females $(p<0.01)$. In the experimental groups, these negative correlations could not be established, only a positive correlation was demonstrated $(p<0.05)$ in males kept at constantly high temperature.

Table 6. Correlation between live weight and malondialdehyde content in thigh muscles of broiler chickens

\begin{tabular}{|c|c|c|c|c|c|}
\hline \multicolumn{3}{|c|}{ Female broiler chickens } & \multicolumn{3}{c|}{ Male broiler chickens } \\
\hline Group & $\begin{array}{c}\text { Correlation } \\
\text { coefficient }\end{array}$ & $\begin{array}{c}\text { Statistical } \\
\text { significance }\end{array}$ & Group & $\begin{array}{c}\text { Correlation } \\
\text { coefficient }\end{array}$ & $\begin{array}{c}\text { Statistical } \\
\text { significance }\end{array}$ \\
\hline 3 & -0.7486 & $p<0.01$ & 4 & -0.6720 & $p<0.05$ \\
\hline 1 & -0.2955 & - & 2 & -0.2955 & - \\
\hline 5 & 0.2808 & - & 6 & 0.6497 & $p<0.05$ \\
\hline
\end{tabular}

Critical value of the correlation coefficient: $r_{n=10, \alpha=0.05}=0.5800 ; \quad r_{n=10, \alpha=0.01}=0.7100$

\section{Discussion}

Breast meat is the most valued part of the broiler. The addition of feed supplement to the diet of the tested chickens had no effect on oxidative processes in breast muscles. The larger variance and occurrence of individuals with low malondialdehyde values in breast muscles in groups fed Energol may be connected with different genetic predispositions, with differences in antioxidative capacity, and with the amount of ingested diet, as well as other factors that are known to affect the lipid oxidation.

Significantly lower malondialdehyde values in breast muscles compared to thigh muscles are connected with the lower fat content. However, the nature of the raw material affects oxidative changes more that the total lipid content (Míková et al. 1992). At lower temperatures, the chemical composition of lipids, the relative abundance of phospholipids and of individual fatty acids has a decisive influence on the stability of the lipid component. It has been known that the muscles of broiler chickens are distinguished by a high content of phospholipids with high proportion of polyene fatty acids, but their quantity markedly differs with respect to the type of muscle concerned. The phospholipid fraction of white muscles, which also include the breast muscles, contains lower amount of unsaturated fatty acids than is present in the red thigh muscles (Igene and Pears on 1979).

Differences in physical activity can significantly contribute to the established differences between breast and thigh muscles. The chickens were kept on deep bedding during the experiment. Šimek and Klecker (2004) describe differences in motor activities between chickens on this technology and those on the conventional cage technology. In stocks on deep bedding, negative correlation between motor activity and feed ingestion was demonstrated. The animals ingested the feed during shorter time intervals, and then they engaged in other activities such as motion. Frankiewicz-Jozko et al. (1996) recorded higher levels of malondialdehyde in thigh muscles of animals showing increased motor activity.

In the thigh muscles, the content of malondialdehyde was significantly lower in chickens fed soybean oil that in chickens fed Energol, the latter having a higher supply of fat with increased proportion of saturated fatty acids. The values measured correspond to data reported by Choi and Byun (1989) on the protective effect of some animal lipids, or their components, on running oxidative processes.

The representation of non-enzyme antioxidants is important in post mortem muscles from the viewpoint of lipid oxidation because these reduce the quantity of oxygen in the environment and, during the terminal stage of oxidation, react with alkoxyl radicals, thus 
preventing their conversion to final products of oxidative degradation (Frankel 1996) or, by chelation, they reduce the redox potential of metals that catalyse the oxidation. As regards antioxidants, all groups of chickens received vitamin E, vitamin A, choline, carotenes and selenium, while the content of the latter two components was increased in groups fed soybean oil.

Carotene intake was augmented in the group fed soybean oil as early as in the first stage of feeding. Carotenes are considered scavengers and deactivators of free radicals in the lipophilic phase in vivo and in vitro (Surai and Kuklenko 2000). Their polyene chain can react with peroxyl radicals, singlet oxygen and other electrophilic species. Carotenes can also be involved in oxidative lipid changes through photochemical reactions. Beta-carotene is active as antioxidant even at a low partial oxygen pressure in active muscles. Under in vivo conditions, $\beta$-carotene can also prevent the oxidation of cysteine component of glutathionperoxidase (Holeček and Racek 1994), glutathione or proteins. The malondialdehyde values measured in the thigh muscles of control and experimental groups are in agreement with these data.

Selenium is a part of the active defence system consisting of interacting antioxidative enzymes (DeVore et al. 1983), which remove not only oxygen but also its active forms from the cellular environment, and can stop the propagation of once started autooxidation processes. Superoxide dismutase, present in cellular mitochondria, breaks down the superoxide and protects reduced glutathione from oxidation. The resulting hydrogen peroxide is eliminated by peroxisomal catalase and by the cytosol or mitochondrial glutathione peroxidase. The post mortem effect of enzyme antioxidants is only indirect, namely by preserving the high antioxidative capacity of non-enzyme antioxidants.

Higher content of copper and also of manganese and iron in the group with soybean oil undoubtedly contributes to the action of enzymatic antioxidants, because these metals are components of antioxidative enzymes. The above-mentioned metals and also other transition elements can initiate lipid oxidation (Velíšek 1999). If ascorbate concentration is high in the system, the free-radical processes catalysed by these metals are significantly suppressed. Š e včík ová et al. (2003) demonstrated the effect of copper supplementation on lipid oxidative stability in broiler chickens.

The differences between groups fed soybean oil and Energol in the recorded values of secondary products of lipid oxidation may also reflect different synergic effects of the antioxidative components present (Palozza and Krinsky 1992). Vitamin E (Bartov et al. 2002; Nam et al. 1997; Surai 2000) and choline (Segawa et al. 1994) might be particularly active in these processes; the amount of choline was reduced in the first two feeding months against the standardized value.

The effect of higher temperatures on lipid oxidation in post mortem muscle tissue has been known and studied in great detail for a long time (Velíšek 1999). These results show that the temperature effect cannot be strictly applied to lipid oxidations in vivo. The inclusion of Energol into the feed rations resulted in non-significant differences in malondialdehyde values in comparison with controls of both sexes if the chickens were kept at elevated temperatures corresponding to heat stress and consumed a diet with reduced amount of nonenzymatic antioxidants. Energol also abolished the negative correlation between live weight and lipid oxidation. Increased lipoperoxidation in thigh muscles of female chickens kept at temperatures of the technological process cannot be considered an undesirable effect of Energol, because this supplement is intended for mitigation of heat stress and thus should not be used at low temperatures in practice, as corroborated by the experiment from the viewpoint of lipoperoxidation.

The experiment has demonstrated that the protein-mineral-energy supplementary feed Proenergol, in combination with the feed supplement Energol, which is intended for 
mitigation of heat stress and with the applied ratio of antioxidative and prooxidative components of feed mixtures BR $1-$ BR 3 , did not significantly $(p<0.05)$ increase oxidative processes of intramuscular lipids of breast and thigh muscles, providing Energol was supplied under increased temperatures corresponding to heat stress. Energol should not be supplied to chickens kept in the temperature regimen according to the technological instruction for COBB 500, because lipoperoxidation significantly increases in thigh muscles under these conditions. At these temperatures, lipid oxidation proceeds more intensively in the muscles of low-weight broilers. Energol abolishes this negative correlation.

\section{Vliv krmiva a teplotního režimu na oxidaci lipidů ve svalech kuřecích brojlerů}

Práce uvádí vliv krmiva a teploty na stabilitu lipidové složky prsní a stehenní svaloviny brojlerových kuřat masného typu hybrida COBB 500. Kuřata byla ustájena v souladu s technologickým postupem. Experimentální skupiny měly v dietě Proenergol v kombinaci s Energolem, kontrolní skupiny Proenergol a sojový olej. U kontrolních skupin a poloviny experimentálních skupin byla teplota snižována v souladu s technologickým postupem, u zbývajících skupin byla udržována na konstantní hladině $31{ }^{\circ} \mathrm{C}$. Výkrm probíhal do stáří 42 dnů. Intenzita oxidace lipidů byla zjištována stanovením malondialdehydu. V prsní svalovině nebyly prokázány rozdíly mezi jednotlivými skupinami kuřat. U stehenní svaloviny se zařazení Energolu projevilo nesignifikantními rozdíly mezi kontrolou a kuřaty chovanými za podmínek tepelného stresu. U kontrolních kuřat krmených sojovým olejem byla zjištěna mezi oxidací lipidů a živou hmotností negativní závislost $(p<0,05)$. U samců s Energolem a chovaných za konstantně zvýšené teploty byla závislost pozitivní $(p<0,05)$.

\section{Acknowledgements}

This research was supported by the Ministry of Education, Youth and Sports of the Czech Republic grant "Veterinary Aspects of Food Safety and Quality" MSM6215712402.

\section{References}

BARTOV I, SKLAN D, FRIEDMAN A 2002: Relationships among vitamin A, D, and E in broiler chicks nutrition. Poult Sci 81: 1385-1391

BASU, AK \& MARNETT, LJ 1983: Unequivocal demonstration that malondialdehyde is a mutagen. Carcinogenesis 4: 331-333

DE VORE VR, COLNAGO GL, JENSEN LS, GREENE BE 1983: Thiobarbituric acid values and glutathione peroxidase activity in meat from chickens fed a selenium- supplemented diet. J Food Sci 48: 300-301

DONKOH A 1989: Ambient temperature: a factor affecting performance and physiological response of broiler chickens. Nt Biometeorol 33: 259-265

DU M, AHN DU, SELL JL 2000: Effect of dietary conjugated linoleic acid and linoleic: linolenic acid ratio on polyunsaturated fatty acid status in laying hens. Poultry Sci 79: 1749-1756

FRANKEL EN 1996: Antioxidans in lipid foods and their impact on food quality. Food Chem 57: 51-55

FRANKIEWICZ-JOZKO A, FAFF J, SIERADZAN-GABELSKA B 1996: Changes in concentrations of tissue free radical marker and serum creatine kinase during the post-exercise period in rats. Eur J App Phys 74: 470-474

GUILLÉN-SANS R, GUZMÁN-CHOZAS M 1998: The thiobarbituric acid (TBA) reaction in foods: A Review. Crit Rev Food Sci Nutr 38: 315-330

HOLEČEK V, RACEK J 1994: Ochrana před volnými radikály pomocí antioxidantů, stopových prvků a léků. Klin Biochem Metab 2: 137-141

HUNTON, P 1995: Poultry production. Elsevier, Hardbound, 600 p.

CHOI JH, BYUN DS 1989: Physiological activity of omega 3 polyunsaturated fatty acids in dark fleshed fishes. 2. Antioxidative effect on lipid peroxidation in rats. Bull Korean Fish Soc 22: 109-114

IGENE JO, PEARSON AM 1979: Effect of triglycerides and phospholipids in the development of warmed-overflavour in meat model systems. J Food Sci 44: 1290

LAURIDSEN C, BUCKLEY DJ, MORRISSEY PA 1997: Influence of dietary fat and vitamin E supplementation on tocopherol levels and fatty acid profiles in chicken muscle membranal fractions and on susceptibility to lipid peroxidation. Meat Sci 46: 9-22

MÍKOVÁ K, HAVLÍKOVÁ L, ANDRASOVÁ A 1992: Sledování oxidačních změn tukové složky mechnicky separovaného drůbežího masa. Průmysl potravin 43: 268-271 
MURRAY RK, GRANNER DK, MAYES PA, RODWEL, VW 2002: Harperova biochemie. Translation, 23. vydání. Appleton \& Lange pp. 241-251

NAM KT, LEEA HA, MINB BS, KANGA CW 1997: Influence of dietary supplementation with linseed and vitamine $\mathrm{E}$ on fatty acids, tocopherol and lipid oxidation in muscle of broiler chicks. Anim Feed Sci Tec 66: $149-158$

NAZIROGLU M, SAHIN K, SIMSEK H, AYDILEK N, ERTAS ON 2000: The effect of food withdrawal and darkening on lipid peroxidation of laying hens in high ambient temperatures. Dtsch Tierärztl Wschr 107: 199-202

PALOZZA P, KRINSKI NI 1992: $\beta$-Carotene and $\alpha$-tocopherol are synergistic antioxidants. Arch Biochem. Biophys 297: 184-187

PARMENTIER HK, NIEUWLAND MG, BARWEGEN MW, KWAKKEL RP, SCHRAMA JW 1997: Dietary Unsaturated Fatty Acids Affect Antibody responses and Growth of Chickens Divergently Selected for Humoral Responses to Sheep Red Blood Cells. Poultry Sci 76: 1164-1171

SAHIN K, SAHIN N, ONDERCI M, YARALIOGLU S, KÜCÜK O 2001: Protective role of supplemental vitamin E on lipid peroxidation, vitamins E, A and some mineral concentrations of broilers reared under heat stress. Vet Med - Czech 46: 140-144

SANZ M, FLORES A, PEREZ DE AYALA P, LOPEZ-BOTE CJ 1999. Higher lipid accumulation in broilers fed on saturated fats than in those fed on unsaturated fats. Br. Point. Sci. 40: 95-101

SEGAWA T, HARA S, TOTANAI Y 1994: Antioxidative behavior of phospholipids for polyunsaturated fatty acids of fish oil. II. Synergistic effect of phospholipids for tocopherol. J Jpn Oil Chem Soc 46: 515-519

SCHNEIDEROVÁ P 2002: Rychlost výkrmu ovlivňuje kvalitu masa brojlerů. Náš chov 11: 12

SUGIHARA NY, TSURUTA Y, DATE K, FURUNO K, KOHASHI K 1994: High peroxidative susceptibility of fish oil polyunsaturated fatty acid in cultured rat hepatocytes. Tox Applied Pharm 126: 124-128

SURAI PF 2000: Effect of the selenium and vitamin E content of the material diet on the antioxidant system of the yolk and the developing chick. Br Poultry Sci 41: 235-243

ŠEVČÍKOVÁ S, SKŘIVÁNEK M, SKŘIVÁNKOVÁ V, TƯMOVÁ E, KOUCKÝ M 2003: Effect of supplementation of copper in copper sulphate and $\mathrm{Cu}$-glycine on fatty acid profile in meat of broiler chickens, cholesterol content and oxidation stability of fat. Czech J Anim Sci 48: 432-440

ŠIMEK, M, KLECKER, D 2004: Welfare a etologie drůbeže po vstupu do EU. Náš chov Tematická příloha chov drůbeže 64: 12-15

TANIZAWA H, SAZUKA Y, TAKINO Y 1981: Micro - determination of Lipoperoxide in the Mouse Myocardium by Thiobarbituric Acid Fluorophotometry. Chem Pharm Bull 29: 2910-2914

VELÍŠEK J 1999: Chemie potravin. OSSIS Tábor pp. 125-139 